\title{
VIOLÊNCIA DE GÊNERO E A AUTONOMIA REPRODUTIVA DA MULHER NA CF/1988: - caso da esterilização judicial compulsória de Janaína sob a análise do discurso crítica
}

\author{
Pablo Florentino Fróes Couto?
}

\section{Palavras-Chave}

pesquisa empírica do direito / análise discursiva crítica / patriarcado / esterilização / direitos reprodutivos

\section{SUMÁRIO}

1. Introdução. 2. Descrição do caso e o contexto da esterilização em massa. 3. O patriarcado e a dominação masculina.

4. Consequências do patriarcado: violência de gênero. 5. Dignidade da pessoa humana e a autonomia reprodutiva da mulher na CF/1988. 6 . Apontamentos da análise do discurso crítica. 7. Análise do discurso crítica do pedido do Ministério Público e da decisão liminar do juiz de primeira instância. 7.1 Identificação do problema social oculto 7.2 Intertextualidade 7.3 Mudança social 8. Conclusão. 9. Referências

\section{Resumo}

O presente artigo, recorte de dissertação de mestrado, apresenta um estudo de caso. Trata-se de uma mulher extremamente pobre que, mesmo contra sua vontade, acabou sendo submetida à esterilização a pedido do Ministério Público e determinada por órgão judiciário de primeira instância. Diante disso, a presente pesquisa empírica do direito bus- cou realizar uma análise discursiva crítica via pesquisa documental e bibliográfica, cujo intento foi dar nitidez ao que estava implícito nos gêneros textuais jurídicos. Com efeito, por meio do estudo dos discursos presentes nas peças processuais, revelou-se quais valores que articularam a prática social na situação em apreço. Dessa maneira, o trabalho analisou o modo como o patriarcado usou - Direito para se praticar a esterilização eugênica. A referida prática em questão acabou causando graves prejuízos aos direitos da vítima. O dano mais notável foi em face de sua autonomia corporal, ou seja, o direito de decidir sobre o próprio corpo, bem como se desconsiderou de maneira nítida a cidadã Janaína enquanto sujeita de direitos, o que feriu frontalmente a dignidade da pessoa humana, princípio de maior estatura da Constituição de 1988. Considerando que a esterilização sem consentimento de pessoas do sexo feminino não é um fenômeno isolado, os movimentos das mulheres juntamente com o despertar da consciência realizada pela ciência crítica entram como meios idôneos para as futuras mudanças sociais.

Bacharel em direito pela Faculdade de Direito Santo Agostinho (FADISA). Especialista em direito processual pela Universidade Estadual de Montes Claros/MG (UNIMONTES) e especialista em direito e processo do trabalho pela Universidade Anhanguera-Uniderp/MS. Mestre em direito constitucional pelo Instituto Brasiliense de Direito Público/DF (IDP). Advogado e professor efetivo do Instituto Federal do Norte de Minas Gerais (IFNMG). 


\section{GENDER VIOLENCE AND THE REPRODUCTIVE AUTONOMY OF WOMEN IN FC/1988: the case of Janaína's compulsory judicial sterilization under analysis of critical discourse}

\section{Pablo Florentino Fróes Couto²}

\section{Key words}

empirical research of law / critical discourse analysis / patriarchy / sterilization / reproductive rights.

\section{Abstract}

The presentarticle, cut froma master's thesis, presents a notorious case study. This is an extremely poor woman who, even against her will, was subjected to sterilization at the request of the Public Prosecutor's Office and determined by a court of first instance. Given This, the present empirical research of the law sought to perform a critical discursive analysis via documentary and bibliographical research, whose intent was to give clarity to what was implicit in legal textual genres. In fact, through the study of the speeches present in the procedural documents, it was revealed what values that articulated the social practice in the present situation. In this way, the work analyzed the way in which the patriarchy used the Law to practice eugenic sterilization. The practice in question ended up causing serious damage to the rights of the victim.
The most notable damage was in the face of her bodily autonomy, that is, the right to decide on her own body, as well as being clearly disregarded the Janaína citizen as subject of rights, which frontally injured the dignity of the human person, principle of greater stature of the Constitution of 1988. Considering that sterilization without consent of the female sex is not an isolated phenomenon, the movements of women together with the awakening of the conscience realized by the critical science enter as suitable means for the future social changes.

2 Bacharel em direito pela Faculdade de Direito Santo Agostinho (FADISA). Especialista em direito processual pela Universidade Estadual de Montes Claros/MG (UNIMONTES) e especialista em direito e processo do trabalho pela Universidade Anhanguera-Uniderp/MS. Mestre em direito constitucional pelo Instituto Brasiliense de Direito Público/DF (IDP). Advogado e professor efetivo do Instituto Federal do Norte de Minas Gerais (IFNMG). 


\section{INTRODUÇÃO}

O artigo é um recorte de uma dissertação de mestrado aprovada em junho de 2019. A pesquisa em tela envolveu um estudo de caso. O pesquisador analisou empiricamente os autos do processo judicial 1001521-572017.8.2017.8.26.0360 em que uma mulher do Município de Mococa/SP, que vivia em extrema pobreza, viciada em álcool e com sete filhos, foi esterilizada judicialmente mesmo contra a sua vontade.

A proposta do presente artigo é analisar discursivamente e criticamente trechos extraídos da ação de obrigação de fazer proposta pelo Ministério Público do Estado de São Paulo e trechos da decisão liminar prolatada pelo juiz de primeira instância. Desse modo, a técnica utilizada foi a pesquisa documental, que incide nos autos do processo que descreveu o caso concreto. O pesquisador teve que buscar livros e revistas com o propósito de captar subsídios teóricos para a análise documental. O método de procedimento que incidiu em cima dos textos jurídicos dos autos foi a análise de discurso crítica.

O caso foi notório em 2018 e chegou a ser divulgado numa reportagem pelo jornal Fantástico da Rede Globo de Televisão ${ }^{3}$. A esterilização partiu de um promotor de Justiça que alegava que Janaína, não tinha condições materiais de sustentar seus filhos, era "viciada em tóxicos", "vivia perambulando pelas ruas" e "representava um perigo para si e para as crianças" (fls. 003 dos autos do processo). Após a alegação do Ministério Público, o magistrado, sem realizar a audiência e sem nomear advogado para patrocinar a defesa de Janaína, determinou

3 Disponível em: < http://g1.globo.com/fantastico/noticia/2018/06/jus tica-determina-esterilizacao-de-mulher-e-causa-polemica.html>. Acesso em: 5 ago. 2018 liminarmente a laqueadura tubária obrigatória. O caso, portanto, acabou gerando preocupação de órgãos internacionais que primam pela proteção dos direitos humanos, como Fundo de População das Nações Unidas (UNFPA) 4 . O assunto deste estudo de caso detém relevância na medida que suscita o debate em torno do poder do Estado patriarcal sobre o corpo da mulher. Com efeito, a temática do trabalho, além de atual, é deveras relevante.

O estudo de caso visa responder a seguinte problemática: de que modo as peças processuais sob análise foram manuseadas discursivamente a ponto de permitirem a violência de gênero que resultou na violação da autonomia reprodutiva de Janaína?

Antes de enfrentar o problema de pesquisa, na segunda seção do artigo, após a introdução, descrevo e contextualizo o caso sob estudo em detrimento das ocorrências históricas de esterilização em massa. Na terceira seção, engendro uma revisão teórica sobre a dominação masculina e o patriarcado, bem como os seus resultados perversos que têm como consequência a violência de gênero, tema tratado na quarta seção. Na quinta seção, parto de uma concepção antropocêntrica ${ }^{5}$ da dignidade da pessoa humana, onde disserto sobre a autonomia da pessoa humana, com um enfoque na autonomia da mulher. Na sexta seção traço apontamentos em torno da análise do discurso com a finalidade de delimitar as categorias analíticas que, aliás, serão aplicadas nas peças jurídicas. Por fim, nas últimas seções, analiso criticamente os trechos das peças jurídicas e busco responder o problema de pesquisa.

Disponivel em: < https://nacoesunidas.org/onu-manifesta-preocupacao-com-esterilizacao-de-mulher-situacao-rua- sp/>. Acesso em: 5 ago. 2018

${ }^{5}$ A concepção antropocêntrica a que se refere o artigo é aquela que coloca o ser humano como o centro do ordenamento jurídico. Isso será mais detalhado na quinta seção do presente artigo científico. 
O objetivo geral do artigo é observar como o Promotor e o Juiz em suas peças jurídicas iniciais reproduziram a violência de gênero. Nessa esteira, o artigo tem como objetivos específicos: identificar a violência oculta nas peças processuais, apontar as intertextualidades, rastrear as falhas argumentativas e textuais e, por fim, refletir criticamente sobre a violência movida pelo patriarcado, cujo impacto reflete na dignidade da pessoa humana.

O método do artigo acadêmico é o dialético. Esse método em tela busca resolver contradições entre duas teorias ou, por exemplo, entre uma teoria (tese) de um lado, e dada a prática social (antítese) do outro. Como resultado, a resolução dessa contradição é denominada de síntese. No estudo de caso em tela, a dignidade da pessoa humana, conceito que contém carga teórica, foi utilizada como tese. Por outro lado, o patriarcado e a consequente violência de gênero, que são práticas sociais interligadas, fizeram o papel de antítese. Diante do ponto de tensão, o uso da ciência crítica e o empoderamento feminino foram a síntese do presente estudo.

Em resumo, pretende-se analisar a forma como o patriarcado conduziu os discursos forenses até optar pela esterilização compulsória de uma pessoa. Como resultado, frisa-se que os problemas sociais foram apontados e depois teorizados conforme o marco teórico da segunda seção deste presente artigo até a quinta seção.

A importância do presente estudo se concentra no propósito de alertar a comunidade acadêmica sobre o perigo do patriarcado, o qual é um regime que coloca as mulheres na condição de "subcidadãs" e subordinadas aos poder masculino. Essa operação patriarcal resultou na desconsideração de

Janaína enquanto sujeita de direitos. Desse modo, colocada na condição de subcidadã, como se fosse um reles objeto, o resultado do processo desprezou um elemento mínimo que faz parte da Janaína e que confere patamar civilizatório às sociedades modernas: a autonomia da pessoa humana. A autonomia é a capacidade do ser humano de decidir sobre sua vida conforme a sua visão de mundo, ou seja, seria um direito do indivíduo de decidir acerca do seu destino sem que o Estado cometa a usurpação da vontade individual.

\section{Descrição do caso e contextos da esteri- lização em massa}

As informações foram extraídas dos autos do processo 1001521-57-2017.8.2017.8.26.0360 disponíveis nas fontes de imprensa ${ }^{6}$ e pelo Tribunal de Justiça de São Paulo na internet?

No dia 29 de maio de 2017, o Ministério Público propôs uma ação de obrigação de fazer de natureza cível pedindo antecipadamente a esterilização compulsória de Janaína. O Ministério Público alegava que a ré não teria condições financeiras e nem psicológicas de prover as necessidades de seus filhos, sendo a requerida usuária contumaz de substâncias entorpecentes e que colocava a própria saúde em risco, bem como dos seus filhos.

Sem a realização de audiência pública, atendendo ao pedido antecipado do Ministério Público, o que significa também a ausência do exercício da ampla defesa, o magistrado (A fonte encontra-se no site: < https://www.revistaforum.com.br/admento-o-caso-e-grotesco/>. Acesso em: 20 fev. 2019.

Endereço do? conversationld=\&pagina Consulta=1\&localPesquisa.cd Lo$\mathrm{cal}=1 \& \mathrm{cbPesquisa}=$ NMPARTE \&tipoNuProcesso=UNIFICADO\&dePesquisa=Jana\% $3 \% A D n a+A p a r e c i d a+Q u i r i n o \& u u i d C a p t-$ cha=\&pbEnviar=Pesquisar\#?cdDocumento=49>. Acesso: em 01 de ago. 2018 
decidiu pela obrigação do Município para que procedesse a laqueadura. No entanto, houve empecilho para o cumprimento da liminar, porque Janaína estava grávida, e a laqueadura em período de gravidez representava alto risco de saúde para a requerida. No entanto, o promotor junta nos autos um documento, onde informa que Janaína, mesmo grávida, foi presa por tráfico de drogas.
Aproveitando a situação em que Janaína estava sob a custódia do Estado, uma vez presa por tráfico de drogas, ela foi esterilizada após dar à luz. Esse fato ocorreu antes mesmo do Tribunal de Justiça de São Paulo apreciar o recurso do Município de Mococa contra a sentença de primeira instância. Com o propósito de compreender a sequência dos fatos, segue, conforme o quadro abaixo, o marco temporal:

\section{Quadro 01 - Cronograma dos principais fatos ocorridos durante o processo.}

\begin{tabular}{|l|l|}
\hline 29 de maio de 2017 & MP propõe Ação de Obrigação de Fazer de natureza cível. \\
\hline 27 de junho de 2017 & $\begin{array}{l}\text { Juiz profere decisão liminar e decide antecipadamente pela laqueadura } \\
\text { compulsória. }\end{array}$ \\
\hline 30 de agosto de 2017 & Município informa que Janaína está grávida. \\
\hline 01 de setembro de 2017 & Ministério Público se manifesta e requer a suspensão da tutela de urgência. \\
\hline 21 de setembro de 2017 & $\begin{array}{l}\text { O Município junta peça processual se defendendo, alega ilegalidade da esterilização } \\
\text { compulsória e pleiteia nomeação de advogado de defesa em prol da Janaína. }\end{array}$ \\
\hline 25 de setembro de 2017 & O Ministério Público rebate as alegações do Município. \\
\hline 05 de outubro de 2017 & O juiz prolata a sentença e determina a esterilização compulsória. \\
\hline $\begin{array}{l}07 \text { de novembro de } \\
2017\end{array}$ & O Município interpõe apelação. \\
\hline $\begin{array}{l}23 \text { de novembro de } \\
2017\end{array}$ & $\begin{array}{l}\text { O Promotor se manifesta e informa ao juízo que Janaína se encontra presa por } \\
\text { tráfico de drogas. }\end{array}$ \\
\hline $\begin{array}{l}28 \text { de novembro de } \\
2017\end{array}$ & Juiz determina que a laqueadura seja feita onde a Janaína se encontra custodiada. \\
\hline 26 de janeiro de 2018 & Promotor faz as suas contrarrazões. \\
\hline 27 de fevereiro de 2018. & Procurador de Justiça faz o seu Parecer. \\
\hline 14 de março de 2018 & Janaína é esterilizada. \\
\hline $\begin{array}{l}23 \text { de maio de } 2018 \text { em } \\
\text { diante... }\end{array}$ & $\begin{array}{l}\text { Tribunal de Justiça de São Paulo declara que a decisão de primeira instância é ilegal } \\
\text { e inconstitucional. }\end{array}$ \\
\hline
\end{tabular}

Fonte - quadro elaborado pelo autor da dissertação.

O presente caso coincide com a realidade dos altos índices históricos de esterilizações praticadas no Brasil contra mulheres. Segundo o requerimento da CPMI de 1992, citada pelo segundo desembargador votante que reformou a decisão, estima-se que 33\% das mulheres casadas entre 15 e 54 anos eram esterilizadas. Por outro lado, em comparação aos países da Europa, o índice de esterilização é em torno de $7 \%$, sendo que na Itália $1 \%$ e na Bélgica 5\%. Com a divulgação dos dados, chegou-se à conclusão de que o índice de esterilização no Brasil é deveras acentuado. Em 2006, o índice de es- 
terilização permaneceu alto no Brasil, sendo que os dados da Pesquisa Nacional de Demografia e Saúde (PNDS), conforme Arilha e Berquó (2009), o índice orbitava em torno de $25,9 \%$.

Percebe-se que a esterilização em massa não é um caso histórico brasileiro, mas, sim, uma conduta que já fora praticada nos EUA e no continente europeu. Geralmente, as esterilizações em massa não ocorrem em face de mulheres da classe alta, mas, sobretudo, contra as mulheres pobres e racializadas.

Nos Estados Unidos, por exemplo, milhares de porto-riquenhas e afro-americanas foram esterilizadas sem seu conhecimento ou consentimento. Esses abusos foram predominantes nos anos 1950, mas também ocorreram em períodos mais recentes. Embora as mulheres porto-riquenhas e afro-americanas fossem, de forma desproporcional, as vítimas mais prováveis dessa negação dos direitos reprodutivos por causa da sua raça e classe, o ataque a esse direito humano fundamental raramente tem sido reconhecido como um dos exemplos mais flagrantes de discriminação racial já perpetrados contra povos racializados nos Estados Unidos. Em geral, a esterilização forçada de muIheres em todo o mundo não tem sido tratada como uma questão racial, embora, quando cuidadosamente examinada, se reconheçam aí fatores de risco, como raça, classe e outros, que determinam quais mulheres, mais provavelmente, sofrerão e quais não sofrerão esses abusos (CRENSHAW, 2002, p.175).

Outra observação pertinente, é que a esterilização feminina traz o problema social que envolve a dominação masculina advinda do patriarcado, em que o destino do corpo das mulheres acaba sendo decidido pelas prescrições masculinas. Como isso acontece? A seção seguinte traz mais detalhes.

\section{O PATRIARCADO E A DOMINAÇÃO MASCULINA}

Pateman (1993) afirma que o contrato social é convencionalmente apresentado como uma história da liberdade. Nesse contrato, os machos trocam o seu medo e a sua insegurança diante de eventual violência física praticada por outros machos pela liberdade civil protegida pelo Estado. No entanto, conforme Pateman (1993), as mulheres, por não terem participado desse contrato social original, elas acabaram, por consequência, sendo qualificadas não a condição de sujeitas de direitos civis como os homens, mas, sim, relegadas a condição de objeto. $\bigcirc$ contrato que coloca as mulheres na condição de objeto é o contrato sexual. Enquanto que no contrato social há liberdade civil do macho salvaguardada pelo Estado diante da ameaça de outros machos, já no contrato sexual ocorre a imposição da sujeição da mulher ao homem. Dentre as cláusulas do contrato sexual, o homem estaria legitimado a exercer sua dominância em face do sexo feminino e teria a chefia da família em suas mãos. Assim, o patriarcado, para Pateman (1993), seria a dominação dos homens sobre os direitos e os corpos das mulheres. Essa dominação seria, portanto, decorrente do cumprimento do contrato sexual.

Saffioti (2004) sintetiza que o patriarcado não se limita a uma relação privada, e sim uma relação com presença em todos os espaços da sociedade (incluindo do Estado). Para a autora, geralmente, o patriarcado confere direitos sexuais dos homens sobre as mulheres, hierarquiza a relação entre gê- 
neros, tem base material, corporifica-se e representa uma estrutura baseada tanto na ideologia, quanto na violência. Para Bourdieu (1999), o Estado reforça as exclusões e as disposições do patriarcado, seja estabelecendo relações paternalistas com as mulheres, seja impondo uma ordem moral conservadora, uma vez que o homem é protagonista das relações de poder.

Saffioti (2004) pondera que, no regime de patriarcado, existem hierarquias entre os homens. Os critérios hierárquicos, usualmente, levam-se em conta a faixa etária, a classe social e a raça. Assim, seguindo esses critérios hierárquicos, os homens brancos, mais velhos e da elite econômica encontram-se próximos do topo da hierarquia. Por outro lado, mulheres sem trabalho, alcóolatras e que vivem em extrema pobreza estão na base da pirâmide hierárquica das relações sociais.

Ainda segundo Saffioti (2004), as mulheres são colocadas no papel de força de trabalho (geralmente doméstico), de objetos de satisfação sexual e de reprodutoras dos homens dominantes. Segundo um estudo conduzido autores Pinheiro, Fontoura, Querino, Bonetti e Rosa (2015), intitulado de "Retrato das Desigualdades de Gênero e Raça", divulgado pelo Instituto de Pesquisa Econômica Aplicada (IPEA), as mulheres, por desempenharem em geral mais atividades domésticas, trabalham em média 7,5 horas a mais do que os homens devido à dupla jornada. Em 2015, ainda conforme o estudo, a jornada média da mulher era de 53,6 horas semanais. Por outro lado, os homens trabalhavam 46,1 horas.

A relação de dominação dos homens em face das mulheres envolve uma mescla de exploração, exclusão e opressão (SAFFIO-
Tl,2004). No Brasil, esse tipo de dominação degradante é mais acentuado. Um dos exemplos que reforçam essa realidade é que - Brasil ocupa a 85a posição em desenvolvimento humano a partir da desigualdade de gênero. Nesse sentido,

[...] a taxa de desemprego das mulheres é cerca de duas vezes a dos homens. [...] o salário médio para os homens é 30\% maior do que o de mulheres. Um terço das famílias brasileiras é chefiada por mulheres, e metade delas é monoparental. O Brasil continua a ocupar o lugar $121^{\circ}$ lugar no ranking de participação das mulheres na política, com as mulheres ocupando pouco mais de 10\% dos assentos no Congresso Nacional. As mulheres também ocupam apenas 10\% das prefeituras e representam $12 \%$ dos conselhos municipais, apesar do cumprimento da lei de cotas (30\%) obtido pela primeira vez nas eleições municipais de 2012."

Apesar das reivindicações das feministas, a reprodução da base material do patriarcado não foi destruída. A dominação-exploração do patriarcado consiste na intensa discriminação salarial entre homens e mulheres, na segregação ocupacional, na marginalização quanto a ocupação de altos cargos na esfera política e empresarial, bem como no controle da sexualidade e da capacidade reprodutiva (SAFFIOTI,2004). Assim, o controle do número de filhos, seja para induzir as mulheres a terem um grande número de crianças, seja para reduzir ou limitar esse número, a decisão estará sempre nas mãos masculinas, embora os elementos femininos possam intermediar estes projetos (SAFFIOTI, 2004).

8 Fonte do trecho citado: ORGANIZAÇÃO DAS NAÇÕES UNIDAS (ONU). Progresso das Mulheres no Mundo: transformar as economias para realizar os direitos, lançado em 27 de abril de 2015. Disponível: <http://progress.unwomen.org/en/2015/\#collapseThree> Acesso em: o8 maio 2019 . 
Bourdieu (1999) afirma que a dominação masculina se localiza nas estruturas históricas que acabam refletindo a ideologia ${ }^{9}$ que prega a supremacia do homem sobre a mulher. Essa ideologia pode, inclusive, residir no inconsciente das pessoas, pois foi tão praticada ao longo da história que acabou sendo naturalizada e aceita de maneira acrítica por parte dos membros das sociedade. Muitos adotam alguma postura ou conduta que reproduz a dominação masculina sem perceber, ou seja, de maneira inconsciente, imperceptível aos olhos de quem a pratica. Seguindo raciocínio do autor, essas ideologias reproduzem socialmente e historicamente características que atribuem a dominância e a superioridade em favor o homem e, por outro lado, colocam um papel de sujeição das mulheres às tarefas tidas na sociedade como menos nobres. Nesse sentido,

[...] cabe aos homens, situados do lado do exterior, do oficial, do público, do direito, do seco, do alto, do descontínuo, realizar todos os atos ao mesmo tempo breves, perigosos e espetaculares, como matar o boi, a lavoura ou a colheita, sem falar do homicídio e da guerra, que marcam rupturas no curso ordinário da vida. As mulheres, pelo contrário, estando situadas do lado do úmido, do baixo, do curvo e do contínuo, vêem ser-lhes atribuídos todos os trabalhos domésticos, ou seja, privados e escondidos, ou até mesmo invisíveis e vergonhosos, como o cuidado das crianças e dos animais, bem como todos os trabalhos exteriores que lhes são destinados pela razão mítica, isto é, os que levam a lidar com a água, a erva, o verde (como arrancar as ervas daninhas ou fazer a jardinagem), com o leite, com a madeira e, sobretudo, os mais sujos, os mais monótonos e mais humildes (BOURDIEU, 1999, p. 41).

\footnotetext{
O pesquisador adota o entendimento sobre o termo "ideologia" de acordo com a concepção de Thompson (1995). Assim, ideologia são discursos e práticas sociais que ostentam relações de dominação de um grupo ou instituição sobre outras pessoas (THOMPSON, 1995).
}

Essas ideologias naturalizam a divisão de papéis entre os sexos, dando um aspecto de que todas as funções arbitrariamente construídas ao longo da história se encontram na ordem natural das coisas. Desse modo, a força da dominação masculina tem amparo social e não necessita de justificação (BOURDIEU, 1999).

Ribeiro (2018) advoga que a mulher foi construída socialmente como o outro, um objeto, algo dotado de função, como a cadeira que serve para sentar ou a caneta que serve para escrever. No mesmo norte, Beauvoir (1980) pontua que o olhar masculino coloca a mulher na situação do outro, o que a impede de "ser para si", de cumprir o papel como sujeita. O mundo não é apresentado para as mulheres com todas as possibilidades e oportunidades.

Ferreira (2014) discorre que a hierarquia entre homem e mulher, nesse cenário, é estabelecida quando o homem é visto como um padrão perfeito, já a mulher é vista como um padrão desviante, uma falha que precisa ser corrigida. O uso do termo homem, por exemplo, foi usado para designar a totalidade das pessoas, o que não gerou incômodo na maior parte dos indivíduos. No entanto, essa designação homogênea foi intencional, o que converge para modelos de pensamentos feitos por homens e para homens, mas imposto para "os outros" ao longo de séculos. Nesse caso, "os outros" se inclui a mulher, como aponta a autora Ferreira (2014). A supremacia e a dominação masculina, seguindo a lição de Bourdieu (1999), advém de estruturas sociais que são produzidas e reproduzidas historicamente e incorporadas como habitus ${ }^{10}$ por homens e mulheres.

${ }^{10} \mathrm{O}$ habitus seria um conjunto de práticas, estilos, jeito de ser, disposições culturais e institucionais, princípios de visão, que acabam incorporando numa classe e por tabela no consciente ou no inconsciente das pessoas pertencentes a esta classe, que acabam se expressando em forma linguagens e comportamento todo esse aprendizado, leciona Bourdieu (1999). 
Retornando para Beauvoir (1980), a mulher é o outro, uma vez que na relação entre os sexos há ausência de reciprocidade por parte do homem, pois a sociedade funciona sob as prescrições masculinas. A mulher é definida tendo o homem como parâmetro. Os homens exercem seu poder político e a sociedade exalta a superioridade masculina, conforme interpreta Santos (2012) ao comentar sobre a obra "O segundo sexo" de Beauvoir (1980).

Santos (2012) discursa que o semelhante é o homem, com quem tem a reciprocidade, com quem comunga com os mesmos poderes, as mesmas relações de trabalho, o mesmo modo de vestir e partilha espaços em comum na sociedade. Já a mulher, que é o outro, não há essa reciprocidade. O homem não partilha com a mulher os mesmos espaços, os mesmos tipos de trabalho e de pensamento. Existe uma relação de dependência da mulher com o poder do homem. Essa relação é de subordinação e opressão.

Saffioti (2001) admite que a dominação pode ser simbólica. Trata-se de uma violência não enunciada, mas silenciosa, implícita, traduzida, por exemplo, na divisão assimétrica do trabalho ou na restrição de certos privilégios ao dominado.

\section{CONSEQUÊNCIAS DO PATRIARCADO: VIOLÊNCIA DE GÊNERO}

O termo gênero é tema debatido entre as autoras feministas. Nas ciências sociais, na esteira de Gomes, Diniz, Araújo e Coelho (2007), o termo surge como categoria teórica para a análise e compreensão da desigualdade que é produzida e reproduzida socialmente ao definir papéis distintos entre homens e mulheres.

Consoante Saffioti (2004), o gênero seria uma categoria que nasce da relação social construída historicamente entre pessoas. Dessa relação, surgem normas modeladoras que servem para analisar a construção social do masculino e do feminino. Logo, o gênero não é só uma categoria histórica, mas também analítica. Ele está ligado ao modo de como as práticas sociais se dirigem aos corpos, em outras palavras, como as características sexuais estão compreendidas ou representadas dentro de um processo histórico, como observa Louro (1997).

Já o termo violência, Saffioti (2004) define como qualquer ruptura à integridade da vítima, seja de ordem física, moral, psíquica e sexual. No caso da esterilização compulsória da Janaína, houve uma violência que teve por consequência uma lesão física, invasiva, irreversível, consistente na mutilação corporal sem o consentimento da vítima.

Ainda conforme Saffioti (2004), as violências psíquicas e morais não são palpáveis, porém são passíveis de serem mensuradas. Existem, ademais, escalas psiquiátricas e psicológicas para se medir as probabilidades de a vítima cometer suicídio em decorrência das violências psíquicas e morais sofridas. As feridas do corpo podem ser tratadas com total êxito, mas as feridas da alma, a probabilidade de $100 \%$ de cura é bem reduzida, pois em muitos casos os danos sofridos são irreparáveis. As violências físicas sofridas, como uma mutilação sem consentimento, ou a violência moral de se presenciar a separação compulsória de uma filha, ambas indubitavelmente podem resultar em profundas feridas na alma.

Saffioti (2001) confere para a categoria violência de gênero um sentido mais geral, em que se abrange violência doméstica e familiar. Para a referida autora, a violência de gênero normalmente ocorre de homem 
contra mulher, mas é possível que ocorra de homem contra homem ou mulher contra mulher, podendo ser vítimas as crianças ou adolescentes de ambos os sexos.

Pondera Saffioti (2001) que, no âmbito do patriarcado, os homens detêm a autorização ou no mínimo tolerância por parte da sociedade para punir quem lhes apresenta como desvio. A execução do projeto dominação-exploração exige a prática da violência muitas vezes. A violência de gênero funciona sob tal chave. Portanto, não faz sentido afirmar que ocorre, por exemplo, uma violência de gênero da mulher contra o marido, haja vista que as mulheres enquanto categoria social não tem projeto de dominação-exploração vigente na sociedade. Por outro lado, faz sentido, segundo Saffioti (2001), sustentar-se a existência de violência de gênero se a mulher, travesti ou transexual, por exemplo, praticar violência contra outra mulher, ou até mesmo contra um homem, se porventura a mulher agressora estiver exercendo as funções patriarcais por delegação sob determinado contexto social. Desse modo, a autora supracitada admite a possibilidade de a violência de gênero ser praticada por uma mulher contra o homem ou em face de outra mulher, desde que ela ocupe a função de patriarca, como é o caso da violência perpetrada por uma professora contra o aluno de escola básica, mãe contra filho sob sua guarda, babá contra criança impúbere, esposa do senhor de engenho contra escravos, por exemplo. O poder atribuído à categoria social "homem" não precisa ser exercido presencialmente por alguém do sexo masculino, pois é possível haver delegação.

Saffioti (2004) afirma que os homens gostam de ideologias machistas e que as muIheres estão socializadas com esse tipo de ideologia machista patriarcal, em que se atribui qualidades positivas e dominantes aos homens. Poucas mulheres questionam esse tipo de inferioridade social, o que não é de se causar surpresa o grande número de mulheres machistas. Desse modo, as mulheres são amputadas de disputar em condições de igualdade o exercício do poder nas relações sociais. Elas são socializadas a terem um comportamento subalterno, dócil, apaziguador e mais frágil para enfrentar uma vida competitiva.

$\mathrm{Na}$ sociedade machista e patriarcal o homem é estimulado a adotar um comportamento mais agressivo, dominante, perigoso e que revele força e coragem. Esse fenômeno Bourdieu (1999) intitulou de incorporação da dominação, onde existe um trabalho de construção simbólica social, profunda, duradoura e difusa sobre as mentes e corpos das pessoas. O resultado é que essas arbitrariedades se tornam habitus da sociedade.

As desigualdades entre homens e mulheres, que acabam traduzindo em contradições ou oposições, acabam desaguando em conflitos sociais, podendo gerar atos de crueldade, intolerância e rejeição plena entre os que não são idênticos.

Tanto o promotor que praticou a maioria dos atos processuais, quanto o juiz do caso Janaína, conforme a mesma entrevista no fantástico, eram homens e brancos para fins de contextualização teórica. Pode-se constatar a aparência do magistrado e do promotor nos links: <https://www.youtube.com/ watch?v=ShXyN49AS5E> e <https://www. youtube.com/watch?v=78vnwpHFXaM\&$\mathrm{t}=566 \mathrm{~s}>$. Ambos os vídeos foram acessados no dia 20 fevereiro de 2019. Juízes e promotores fazem parte do alto escalão do funcionalismo público do Estado. De acordo com 
o ranking elaborado pelo professor José Roberto Afonso do Instituto Brasiliense de Direito Públicon", promotores e juízes ocupam o segundo lugar dentre os funcionários mais bem remunerados do país, perdendo o posto apenas para os titulares de cartório. Portanto, em tese os dominadores que exerceram preponderantemente a função patriarcal no caso concreto foram homens, brancos e pertencentes a uma elite estatal. Para a Saffioti (2004), na ordem patriarcal o poder é prevalentemente macho, branco, rico e de preferência heterossexual. As mulheres estão em desvantagem, o que as coloca numa posição mais vulnerável de sofrer as violências. O patriarcado, como o próprio nome indica, é o regime de dominação-exploração das mulheres pelos homens. Noutro norte, em contraste com os agentes do Estado, estava a Janaína, uma mulher negra ${ }^{12}$ extremamente pobre e que vivia em estado de drogadição.

Observando ainda as reflexões da Saffioti (2004), tanto o promotor, quanto o juiz, a priori, adotaram comportamentos dominantes, invasivos, audaciosos e agressivos. A dominância, a coragem e a força do promotor residiram no momento quando o mesmo postulou um pedido que lesou expressa previsão legal, além de ter pleiteado uma tutela antecipada para que o processo tivesse tramitado de forma mais célere, pois certamente tal tese não se sustentaria no tribunal de justiça.

Quanto ao magistrado, todas essas características de dominância, descritas pela Saffioti (2004), concentraram-se no seu poder de

Publicado no site: <https://jornalggn.com.br/gestao-publica/mem bros-do-mp-e-do-judiciario-estao-entre-os-mais-bem-pagos-do-pais/>. Acesso em: 12 fev. 2019.

${ }^{12}$ Vide reportagem com foto e vídeo de Janaína no site: < https://gl globo.com/sp/sao-carlos-regiao/noticia/liminar-do-tj-sp-concede-liberdade-para-mulher-esterilizada-apos-decisao-da justica.ghtml> Acesso em: 22 out. 2018

decisão que determinou a violência perpetrada contra a Janaína. A coragem e a audácia se sucederam pelo fato do magistrado ter conduzido um processo sem a oitiva da ré, que nem sequer teve direito à assistência a uma advogada para poder exercer sua defesa.

O patriarcado, para manter sua hegemonia, costuma punir quem se mostra como desvio. A Janaína era o desvio. Essa violência de gênero, resultado da operação patriarcal, lesou a autonomia corpo feminino da vítima, direito constitucionalmente protegido.

\section{DIGNIDADE DA PESSOA HUMANA E A AUTONOMIA DA MULHER NA CF/1988.}

O autor renascentista Conde de Mirândola e Concórdia (1999) leciona que a autonomia humana envolve, antes de tudo, a capacidade do ser humano de decidir sobre os rumos de sua vida. Sarmento (2016) esclarece que a autonomia envolve o ser humano enquanto sujeito moral, racional, capaz de tomar decisões, julgar o que é bom ou mau para si e seguir o seu caminho escolhido, desde que não infrinja direito de terceiro. As escolhas são existenciais, logo abarcam decisões de ordem afetiva, reprodutiva, intelectual, profissional, filosófica ou ideológica, por exemplo. Seguindo a trilha, as motivações das escolhas são adstritas ao mundo subjetivo do indivíduo e não precisa fazer sentido para outras pessoas, mas mesmo assim devem ser respeitadas (SARMENTO, 2016).

A autonomia advém do princípio ${ }^{13}$ da dignidade da pessoa humana. Faz parte do seu conteúdo material. Moraes (2010) afirma que o conteúdo do referido princípio corres-

${ }^{13}$ Princípio significa "[...] mandamento nuclear de um sistema, verdadeiro alicerce dele, disposição fundamental que se irradia sobre diferentes normas compondo-lhes o espírito e sentido servido de critério para sua exata compreensão e inteligência, exatamente por definir a lógica e a racionalidade do sistema normativo, no que lhe confere a tônica e lhe dá sentido harmônico". (MELO, 2009, p.882). 
ponde à compreensão do indivíduo na comunidade, onde os sujeitos se reconhecem entre si como dotados de autodeterminação, iguais nos aspectos formal e material e merecedores de respeito à integridade psicológica e física.

Barretto (2010) acrescenta que o conteúdo do princípio envolve o encargo do Estado de cobrir as necessidades vitais das pessoas. Barroso (2012) sintetiza o conteúdo da dignidade da pessoa humana em três pilares: a) valor intrínseco (não tratar o indivíduo como meio ou não instrumentalizá-(o); b) autonomia; c) valor comunitário (restrição de direitos individuais em prol da proteção de direitos de terceiros).

A dignidade da pessoa humana, segundo Sarmento (2016), consiste no reconhecimento da humanidade na posição hierárquica superior em detrimento dos demais seres habitantes do globo terrestre. Essa superioridade decorre da racionalidade humana. Ao contrário dos animais, que não conseguem superar os instintos e o modo de vida mecânico, o ser humano pensa, delibera e reflete sobre a própria existência (RABENHORST, 2010).

O indivíduo da espécie humana é o parâmetro para dizer o que as coisas são e o que não são. Sem a razão e reflexão humana, nada presente na natureza questionaria a essência das coisas. Assim, o ser humano é o juízo de toda a realidade, capaz de descrevê-la e perguntar sobre ela (WATANABE, 2001).

No âmbito constitucional brasileiro, bem como nas cortes constitucionais de todo o mundo, a dignidade da pessoa humana vem tomando substancial força, adquirindo feições de princípio constitucional de estatura máxima (BARROSO, 2012). Sarmento
(2016) leciona que a dignidade da pessoa humana tem múltiplas funções e diversos objetivos no ordenamento jurídico. O autor supracitado exemplifica que a dignidade serve para identificar e limitar o âmbito de atuação dos direitos fundamentais ${ }^{14}$, norteia a hermenêutica jurídica, além de controlar a validade de atos emanados pelo Estado e pelos particulares. Tepedino (1999) salienta que a dignidade da pessoa humana tem por escopo a proteção integral da personalidade e dos direitos da pessoa humana, o que rechaça eventuais pretensões de proteção recortada.

Aponta Sarmento (2016) que, na Constituição brasileira de 1988, a premissa axiológica da dignidade da pessoa humana parte de um fundo altamente antropocêntrico e humanista. A Carta de 1988, assim como as Constituições europeias pós-guerra, trata o ser humano com centralidade, como um fim, rechaçando, portanto, qualquer tentativa de firmar o indivíduo como um meio. Por consequência, os direitos fundamentais das pessoas humanas foram consagrados como cláusulas pétreas (art. $60 \S 4^{\circ}$, inciso IV da CF).

No direito brasileiro, a Carta de 1988 reconheceu a dignidade da pessoa como fundamento da república e do Estado Democrático de Direito (art. $1^{\circ}$, III da CF). O constituinte de 1988 não listou a dignidade da pessoa humana no rol dos direitos fundamentais, mas, sim, como valor fundamental (SARLET, 2009). Enquanto norma jurídica-positiva, o referido princípio define direitos, garantias e

${ }^{14}$ Sobre direitos fundamentais: "[...] os direitos fundamentais são também conhecidos como direitos humanos, direitos subjetivos públicos, direitos do homem, direitos individuais, liberdades fundamentais ou liberdades públicas. A própria Constituição da República de 1988 apresenta diversidade terminológica na abordagem dos direitos fundamentais, utilizando expressões como direitos humanos (artigo $4^{\circ}$, inciso II), direitos e garantias fundamentais (Título II e artigo $5^{\circ}$, parágrafo $1^{\circ}$ ), direitos e liberdades constitucionais (artigo $5^{\circ}$, inciso LXXI) e direitos e garantias individuais (artigo 60, parágrafo $4^{\circ}$, inciso IV)." (IURCONVITE, 2007 p.01) 
deveres fundamentais. A dignidade da pessoa humana, ainda conforme Sarlet (2009), gera direitos subjetivos de cunho negativo. Em outras palavras, no sentido de não violação ao princípio da dignidade, bem como direitos subjetivos de cunho positivo, ou seja, no sentido de proteger e promover o referido princípio.

Todos os órgãos do Estado e todos os indivíduos estão vinculados ao princípio da dignidade da pessoa humana, havendo o respeito e a consideração como imperativo (SARLET, 2009). O Estado deve promover um ambiente para que todos gozem de dignidade, bem como deve remover todos os obstáculos que impeçam a eficácia da aplicação do referido princípio (PÉREZ, 1986).

Sarlet (2009) faz a reflexão de que o princípio em apreço não apenas apresenta um conteúdo ético e moral, mas também se trata de norma constitucional formal e material que apregoa um valor jurídico fundamental da comunidade. Para Martins-Costa (2001), a dignidade da pessoa humana confere o ânimo e ao mesmo tempo representa um valor que justifica a existência do próprio ordenamento jurídico.

Nas lições de Sarmento (2016), a Constituição de 1988 traduz a ideia, graças ao princípio da dignidade da pessoa humana, de que o Estado e o direito existem para as pessoas, não ao contrário. Nessa conjuntura, o Estado e o direito servem como instrumentos para servir os cidadãos.

O aspecto intrínseco da dignidade da pessoa humana, conforme Sarmento (2016), reside no fato de que nenhum indivíduo pode ser instrumentalizado pelo Estado, por particulares e nem por maiorias políticas. Todos devem ser tratados como sujeitos de direitos, enquanto agentes, não como objetos, como se fossem cabeças de gado.

O aspecto intrínseco da dignidade da pessoa humana, segundo Sarmento (2016), é ontológico, ou seja, independe de status, da conduta, do gênero, da idade, da nacionalidade e da capacidade mental, enfim, todas as pessoas indistintamente detêm a dignidade por simplesmente serem pessoas. Esse aspecto intrínseco jamais pode ser perdido.

Informa Sarmento (2016) que o aspecto intrínseco coloca o ser humano na posição de protagonista. Assim, o Estado existe para o indivíduo e, não, ao contrário. O ângulo intrínseco coloca o ser humano como um fim em si mesmo, capaz de se autodeterminar e de fazer escolhas. Desse modo, o Estado não deve governar os indivíduos sem o respaldo do seu consentimento e nem tratá-los de forma degradante (SARMENTO, 2016).

No entanto, as intromissões patriarcais desafiam o princípio da dignidade da pessoa humana, especialmente quanto ao conteúdo da autonomia reprodutiva da mulher.

Rodotà (2006), em relação aos direitos reprodutivos femininos, indaga "de quem seria o corpo?" Em seguida, o mesmo autor ensaia outras perguntas decorrentes da primeira.

Da pessoa interessada, do seu círculo familiar, de um Deus que Ihe doou, de uma natureza que o quer inviolável, de um poder social que de mil maneiras dele se apossa, de um médico, de um magistrado que estabelecem o seu destino? E de qual corpo estamos falando? (RODOTÀ, 2006p73).

Após as indagações de cunho filosófico, Rodotà (2006) afirma que, durante muito tempo, os paradigmas diziam que o corpo pertencia à natureza e às regras do poder que tolhiam a conduta e a liberdade do corpo durante a vida cotidiana. Hoje essa coerção, 
segundo Rodotà (2007), é exercida pelas normas, pelo direito e pela disciplina humana. O problema reside, conforme o autor, quando o direito reproduz as ambições controladoras da sociedade sobre o corpo feminino. Rodotà (2006) dá o exemplo das regras jurídicas que conferiam poder do marido sobre o corpo da esposa.

No direito brasileiro, até relativamente pouco tempo atrás, havia disposições patriarcais, como a necessidade de a mulher conseguir autorização do marido para que pudesse exercer, fora do lar conjugal, qualquer profissão, o que foi previsto no art. 233 do Código Civil de 1916 que vigorou até 11 de janeiro de 2003. Tinha a proibição de a mulher casada aceitar tutela, curatela ou qualquer outro múnus público, herança, legado e mandato sem autorização do cônjuge varão (art. 242 do Código Civil brasileiro de 1916). O Código Civil em tela que ora foi revogado reproduzia os padrões patriarcais de família que são dominantes na sociedade brasileira (ALVES, 2010).

Em sentido contrário ao Código Civil de 1916, a Constituição de 1988 trouxe avanços no quesito autonomia humana. Sarmento (2005) e Barboza e Almeida Junior (2017) afirmam que, além do planejamento familiar, a autonomia da mulher, sobretudo no campo reprodutivo, é extraída dos seguintes dispositivos constitucionais: a) dignidade humana da mulher (art. $7^{\circ}$, III da CF); b) direitos fundamentais de liberdade e privacidade (art $.5^{\circ}$ caput e inciso X da CF). Sendo assim, fica assegurada à mulher a autonomia para decidir sobre seu corpo quanto ao desejo de querer ter filhos ou não (BARBOZA; ALMEIDA JUNIOR, 2017). Esses pontos levantados reforçam o repúdio a qualquer tentativa de coerção contra a mulher (SOUSA, 2010), bem como qualquer tentativa de "coisificação" (CORRÊA; PETCHESKY, 1996). Do outro lado, caberá ao Estado assegurar meios materiais para a mulher exercitar seus direitos reprodutivos, restando proibido qualquer abuso autoritário contra ela (BARBOZA, 2008).

Existem mais direitos constitucionais que acabam dialogando, circulando e protegendo os direitos reprodutivos da mulher (JARDIM, 2005). Sob essa ótica, destacam-se os princípios constitucionais referentes à cidadania (art. $1^{\circ}$, II da CF), a promoção do bem- estar de todos sem preconceito de origem, raça, sexo, cor, idade e qualquer outra forma de discriminação (art.3, IV da CF).

Quanto à saúde reprodutiva e ao planejamento familiar, ambos se situam na ordem social no Título VIII da Constituição. O art. 196 da Constituição consagrou o direito à saúde como "[...] direito de todos e dever do Estado, garantido mediante políticas sociais e econômicas que visem à redução do risco de doença e de outros agravos e ao acesso universal e igualitário às ações e serviços para sua promoção, proteção e recuperação." Segundo Jardim (2005) e Buglione (2003), a saúde reprodutiva deve ser interpretada levando em consideração os parâmetros de saúde definidos pela Conferência do Cairo de 1994 e da Organização Mundial de Saúde. Logo, a saúde deve prover o bem-estar físico, mental e social em prol das pessoas. A saúde reprodutiva não se restringe apenas à cura de doenças ou ao mundo prescritivo. Ela visa promover a diversidade, a prevenção, a não discriminação, o respeito às diferenças, o acesso à informação, em suma, deve promover um tratamento mais humanitário aos indivíduos em consonância com o princípio da igualdade e da dignidade da pessoa humana (BUGLIONE, 2003; JARDIM, 2005). 
Em relação ao campo das liberdades, a

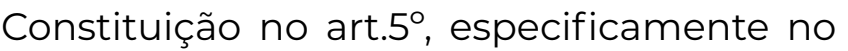
inciso II, estabelece que ninguém será obrigado a fazer ou deixar de fazer alguma coisa, exceto se a lei exigir. Já no inciso XLI do mesmo artigo, o dispositivo prevê punição em face de particular ou do agente do Estado que praticar formas de discriminações que atentem contra os direitos fundamentais. Por fim, no inciso LV do art. $5^{\circ}$ em apreço, dispõe que as partes envolvidas em processos judiciais ou administrativos, bem como aos acusados em geral, têm o direito fundamental ao contraditório e ampla defesa. Isso significa que nenhum cidadão pode sofrer constrições dos seus direitos reprodutivos por parte do Estado sem previsão legal, sem direito à defesa, sem contraditório ou então por motivos discriminatórios, seja de gênero, de classe, raça ou de qualquer outra condição. Em outras palavras, os dispositivos estabelecem liberdades negativas para o Estado, em suma, há uma obrigação estatal de não violar as liberdades individuais dos jurisdicionados. Quanto ao inciso XLI do art. $5^{\circ}$, o dispositivo vale igualmente para os particulares. De outro modo, ninguém pode ser discriminado por exercer suas liberdades sexuais e reprodutivas, seja a discriminação oriunda do Estado ou de outras pessoas.

Por fim, tendo como base esse marco teórico levantado, buscar-se-ão mais respostas ao seguinte questionamento durante a análise crítica do discurso: quais as especificidades discursivas do caso Janaína que resultaram em prejuízos na sua autonomia reprodutiva? No entanto, antes de adentrar no mérito da pesquisa, traçar-se-ão alguns apontamentos sobre a análise de discurso crítica.

\section{APONTAMENTOS DA ANÁLISE DO DISCURSO CRÍTICA}

De acordo com Melo (2018), a linguagem não se limita ao uso da comunicação, ela permite construir a visão subjetiva dos falantes sobre o mundo, sobre si próprios, ajudando a construir identidades de si e dos outros. Ela revela como são as relações dos falantes entre si, com as instituições, com as estruturas socioeconômicas da sociedade, além de expor o cunho ideológico que permeiam essas relações. De outro modo, é por meio da linguagem dos textos que se coleta quem são os grupos dominantes, os grupos dominados, as relações institucionalizadas e as ideologias que se confrontam ou que estão em vigor. Para Fairclough (2001), a linguagem está diretamente ligada aos processos sociais e culturais. Portanto, nesse cenário entra a importância da análise linguística como um procedimento que visa estudar as mudanças sociais.

O discurso, para Fairclough (2001), enfatiza a interação entre o produtor da fala e o receptador, o escritor e o leitor e, por consequência, os processos de produção da escrita e da fala, os processos de interpretação, além dos contextos por trás desses processos.

O discurso é uma ação sobre o mundo e sobre as pessoas. Ele desenvolve uma relação dialética com as estruturas sociais, pois constitui, constrói e, ao mesmo tempo é moldado por elas. Em outras palavras, o discurso é moldado pela classe, por instituições privadas (como empresas, por exemplo), pelo direito, pelo sistema educacional e assim por diante, observa Fairclough (2001). O autor supracitado defende o discurso como prática política, que estabelece, mantém e transforma as relações de poder entre os cidadãos, entre as entidades 
coletivas ou entre indivíduo e entidade. Ele também defende o discurso como prática ideológica, pois este constitui, naturaliza, mantém ou transforma as visões de mundo nas mais diversas posições das relações de poder. Para o referido autor, a prática discursiva contribui para reproduzir todo o corpo social (identidades sociais, relações sociais, sistemas de crença ou de conhecimento) como ele é, bem como ajuda a transformá-lo (FAIRCLOUGH, 2001).

A Análise do Discurso Crítica (ADC) é um campo de estudo que busca descrever, explicar e revelar o envolvimento da linguagem com o funcionamento da sociedade contemporânea. Segundo Colares (2014), a Análise do Discurso Crítica, mormente no campo do Direito, visa dar visibilidade ao que está oculto nos gêneros textuais jurídicos. Desse modo, nos textos produzidos pelos profissionais do direito fluem significados que refletem as suas visões sobre o mundo e que também podem servir de manipulação ideológica.

Conforme Melo (2018), o uso "crítico" da ADC vem das ciências críticas oriundas das teorias trabalhadas pelos estudiosos de orientação marxista da Escola de Frankfurt. Segundo Wodak (2001), esses teóricos tomaram como ponto de partida os problemas sociais latentes que afligiam a sociedade e, diante desses problemas, adotaram uma postura de criticidade, com viés político, no sentido de conduzir pesquisas com intuito de transformar a realidade social opressora e resolver os problemas predominantes. De acordo com a autora supracidada, essa postura crítica visa desnaturalizar o que é dado como natural e que passa muitas vezes como problemas não visíveis. Em outras palavras, a postura crítica visa dar visibilidade ao estado de exploração e opressão, além de desnaturalizá-lo. Continua Wodak (2001) que as ciências críticas têm caráter reflexivo, pois se reconhecem no mundo como objeto e adotam postura de engajamento.

A ADC envolve processos de produção e interpretação de textos enquanto práticas sociais de várias instituições que exercem as relações de poder e hegemonia social. O seu objeto, portanto, é investigar o uso da linguagem no intuito de descobrir o significado dos contextos sociais por trás dos textos. Trata-se de forma resumida de uma combinação de análise textual com análise social. Para tanto, ela se vale do modo de como as palavras são articuladas, o seu sentido, a semântica, a forma gramatical, sem perder, porém, o foco nas questões sociais, sobretudo nas situações que revelem assimetrias de poder. Em suma, a intenção é desvelar o modus operandi de como os discursos reproduzem e constroem ao mesmo tempo a dinâmica da sociedade, sintetizam Batista Junior, Sato e Melo (2018).

De acordo com Chouliarraki e Fairclough (1999), compreender o modo de como os discursos fluem dos textos significa observar a forma de como as práticas sociais se articulam. A análise do discurso acaba servindo como método de procedimento para conduzir uma pesquisa sobre essas questões (FAIRCLOUGH, 2001; COLARES, 2014).

O corpus, ou os dados selecionados do presente artigo, são os trechos transcritos da ação de obrigação de fazer do Ministério Público e a decisão liminar do juiz de primeira instância que deferiu a pretensão do Parquet. Todos os trechos foram enumerados para facilitar a leitura e a compreensão da análise que o trabaIho científico pretende fazer.

A referida análise parte de uma ideia traduzida no marco teórico, que é a operação do 
patriarcado que culminou na violência judicial de gênero. De outra maneira, o objeto do presente trabalho é a descrição, intepretação e análise de textos jurídicos a partir de um marco teórico.

O método de procedimento contém algumas etapas. Há, primeiro, a identificação do problema social oculto, que por sua vez está contido nas entrelinhas do texto, bem como reflexões acerca do referido problema.

Em segundo lugar, existe o exercício da intertextualidade, que é um dos focos principais da análise do discurso. A intertextualidade aponta o modo de como o texto cita outros textos anteriores a ponto de reestruturá-los ou transformá-los diante de uma dada situação fática. A intertextualidade " [...] implica uma ênfase sobre a heterogeneidade dos textos e um modo de análise que ressalta os elementos e as linhas diversos e frequentemente contraditórios que contribuem para compor um texto (FAIRCLOU$\mathrm{GH}, 2001$, p.137)."

A intertextualidade se divide em alguns espécimes. $O$ artigo não tratará de todos os espécimes, mas apenas da intertextualidade atribuída ou manifesta, não modalizada e destacada, que foram encontradas ao longo dos fragmentos transcritos.

Existe a intertextualidade atribuída ou manifesta, que são a citações de autores ou das leis no próprio texto. Há a intertextualidade não modalizada, que consiste em afirmações categóricas que expressam uma verdade (isso é, isso deve, não há dúvida). Por fim, a intertextualidade destacada se refere às suposições ocultas no texto (FAIRCLOUGH, 2003).

A partir da intertextualidade se abstrai que os autores não produzem o texto so- zinho. Percebe-se, outrossim, quem fala no texto e quem não fala (FAIRCLOUGH, 2003).

Com efeito, quem exerce o protagonismo do texto? Quem está sendo omitido? Quais textos estão sendo citados na decisão ou na ação de obrigação de fazer? Quais foram omitidos? Ademais, é através da intertextualidade que se verifica como o texto está sendo legitimado através de outro, ou seja, como esse texto é tido como algo verdadeiro (FAIRCLOUGH, 2003). Por exemplo, se o promotor faz uma afirmação na peça exordial, em qual lei ou autor ele está fundamentando essa afirmação?

Em terceiro lugar, após a identificação do problema social oculto, sua reflexão com base no marco teórico e a aplicação da intertextualidade, o artigo aponta as possíveis soluções para o problema, buscando a mudança social (FAICLOUGH, 2001).

O analista do discurso, conforme Fairclough (2001), é livre para analisar o controle interacional do texto, a coesão, gramática, a transitividade, o significado de cada palavra e as metáforas. Entretanto, como o artigo tem mais um viés de análise jurídica do que linguística, limitar-se-á a análise quanto à unidade lógica do raciocínio jurídico adotado (coesão).

Em suma, alguns métodos trabalhados por Fairclough (2001) serão utilizados no presente trabalho. A análise do discurso será feita sob o prisma da coesão e intertextualidade. Identificar-se-á o problema social contido nas entrelinhas dos fragmentos analisados à luz do marco teórico levantado neste artigo. Apontar-se-ão as consequências sociais do problema oculto e mudanças sociais serão propostas. 


\section{ANÁLISE DO DISCURSO CRÍTICA DO PEDIDO DO MINISTÉRIO PÚBLICO E DA DECISÃO LIMINAR DO JUIZ DE PRIMEIRA INSTÂNCIA}

A pesquisa omitiu nas peças processuais a identificação das autoridades e dos filhos da pessoa envolvida (foi utilizado XXX no nome das crianças) por razões éticas. Contudo, a identificação do prenome da Janaína foi mantida ante a notoriedade do caso.

Destacamos o seguinte trecho do pedido de liminar por parte do Ministério Público:

1.A requerida já é mãe de cinco filhos ( $X X X$, $X X X, X X X, X X X$ e $X X X)$, todos menores, 2.que já estiveram acolhidos na Casa de Acolhimento Bethânia, nesta cidade de Mococa, 3.considerando que a mãe não teria condições de prover as necessidades básicas de seus

4.rebentos, além de colocá-los, frequentemente, em potencial risco em razão do uso de

5.álcool e outras drogas.

6.Por tal razão, foi recomendada pelos equipamentos de saúde e de assistência social

7.deste Município a realização de laqueadura tubária da requerida Janaína como método

8.contraceptivo.

9.Não obstante, conforme já afirmado e de acordo com os ofícios cujas cópias instruem a

10.presente, a requerida constantemente é encontrada perambulando pelas ruas da cidade

11.com claros sinais de uso abusivo de álcool e drogas. Janaína, em determinados 12.momentos, manifesta vontade em re- alizar o procedimento de esterilização; noutros,

13.demonstra desinteresse ao não aderir aos tratamentos e ao descumprir as mais simples

14.orientações dos equipamentos da rede protetiva.

15.Diante de tal quadro fático, não há dúvidas de que somente a realização de 16.laqueadura tubária na requerida será eficaz para salvaguardar a sua vida, a sua 17.integridade física e a de eventuais rebentos que poderiam vir a nascer e ser 1colocados

18.em sério risco pelo comportamento destrutivo da mãe.

19.Isso porque, repita-se, mesmo após várias tentativas, a requerida não adere aos 20.tratamentos ambulatoriais propostos.

O pedido do Ministério Público foi fundamentado nos seguintes dispositivos no art. $1^{\circ}, 111,5^{\circ}, 6^{\circ}, 196$ e art. 23, inciso, II, combinado com o art. 198, todos da Constituição Federal. Além disso, invocou-se o art. $1^{\circ}$ da lei 9.263/1996 e arts. $2^{\circ}, 6^{\circ}$ e $7^{\circ}$ da lei 8.080/1990. Ao final da fundamentação, destaca-se o seguinte trecho da peça processual inicial do Parquet:

21.Assim, não resta alternativa ao Ministério Público senão o ajuizamento da 22.presente ação para compelir o MUNICÍPIO a realizar a laqueadura tubária em 23.Janaína, bem como para submetê-la a tal procedimento mesmo contra a sua vontade,

24.tudo em conformidade com o disposto na Lei $n^{\circ} 9.263 / 96$ e preceitos constitucionais

25.que consagram a saúde como dever 
do Estado e direito de todos.

26.Logo, trata-se de direito inserto no chamado 'mínimo existencial', cuja garantia é

27.obrigação e responsabilidade do Estado, mormente à luz do princípio da dignidade

28.da pessoa

\section{DA TUTELA DE URGÊNCIA}

30.Uma vez demonstrados, de um lado, o direito subjetivo da requerida, e, de outro, 31.o dever do Estado no fornecimento de serviços de saúde, sobretudo com caráter de 32.urgência, e sua omissão e inércia, a tutela de urgência é indispensável, a fim de que

33.o requerido MUNICÍPIO DE MOCOCA seja compelido a garantir a JANAÍNA 34.APARECIDA QUIRINO a realização de laqueadura tubária, precedida do

35.indispensável laudo médico, nos termos do artigo 10, inciso II, da Lei $\mathrm{n}^{\circ}$ 9.263/96,

36.e conforme recomendado pelos equipamentos públicos de saúde e assistência 37.social de Mococa.

O juiz de primeira instância defere a liminar. Segue a decisão do Juiz:

\section{Vistos}

39. Verifica-se dos autos que a parte a requerida Janaína necessitar realizar cirurgia de

40.laqueadura tubária, pois é pessoa hipossuficiente, apresenta grave quadro de 41.dependência química, sendo usuária contumaz de substâncias entorpecentes, além

42.de ser mãe de cinco filhos, que já estiveram acolhidos na Casa de Acolhimento
43.Bethânia, nesta cidade. E, a princípio, não tem condições financeiras de arcar com os 44.correspondentes custos

45.No mais, note-se que as diversas normas citadas na inicial demonstram à saciedade a 46.obrigação da União, do Estado e do Município ampararem integralmente, com todos os

47.meios e recursos existentes, toda e qualquer pessoa que necessite de assistência médica

48.e/ou medicamentosa, desde que não possam arcar com tais necessidades sem prejuízo

49.de sua própria subsistência

50.De fato, a Constituição Federal, em seu art. $6^{\circ}$, dispõe que:

51."Art. 6. São direitos sociais a educação, a saúde, o trabalho, o lazer, a segurança, a 52.previdência social, a proteção à maternidade e à infância, a assistência aos 53.desamparados, na forma desta Constituição".

54.Por outro lado, dispõe o art. 196 da Carta Magna:

55."A saúde é direito de todos e dever do Estado, garantindo mediante políticas sociais

56.e econômicas que visem à redução do risco de doença e de outros agravos e ao 57.acesso universal e igualitário às ações e serviços para sua promoção, proteção e 58.recuperação".

59.Já o art. 223, I e V, da Constituição Estadual dispõe que: 
60."Art. 223. Compete ao sistema único de saúde, nos termos da lei, além de outras 61.atribuições:

62.I - a assistência integral à saúde, respeitadas as necessidades específicas de todos os

63.seguimentos da população; (...)

$64 . V$ - a organização, fiscalização e controle da produção e distribuição dos 65.componentes farmacêuticos básicos, medicamentos, produtos químicos, 66.biotecnológicos, imunobiológicos, hemoderivados e outros de interesse para a 67.saúde, facilitando à população o acesso a eles".

68. Regulamentando tal dispositivo constitucional, que pelo seu conteúdo e extensão, já

69.revela tratar-se de norma de eficácia social (v. DINIZ, Maria Helena, Norma 70.Constitucional e seus Efeitos, São Paulo: Ed. Saraiva, p.56/58),

71.a Lei $n^{\circ} 8.080 / 90$, em seu artigo $6^{\circ}$, veio a dispor que:

72."Art. 6. Estão incluídos ainda no campo de atuação do Sistema Únicos de Saúde -SUS:

73.I - a execução de ações:

74.(...)

75.d) de assistência terapêutica integral, inclusive farmacêutica".

76. Note-se que a situação da requerida Janaína demanda grande atenção, 77.principalmente por seu estado físico.

78.Ademais, em relatório minucioso a psicólogo judicial confirma a intenção de 79.Janaína em se submeter à cirurgia de laqueadura tubária, inclusive firmando a ré

80.Janaína a declaração de fl. 29, peran- te à Supervisora de Serviços do Segundo Ofício

81.Judicial do Município.

82.Assim, defiro em parte a antecipação da tutela, para determinar que a 83.Municipalidade ré realize na requerida Janaína Aparecida Quirino a cirurgia de 84.laqueadura tubária.

Então, resta fazer uma análise do discurso dos trechos destacados, que somam $84 \mathrm{li}$ nhas e todas estão enumeradas para facilitar a leitura. A análise do discurso foi dividida em três etapas: identificação do problema social oculto, intertextualidade e mudanças sociais.

\subsection{Identificação do problema social oculto}

A primeira etapa consiste em identificar o problema social contido nas entrelinhas dessa decisão à luz da proposta teórica que foi apresentada nas seções anteriores do referido trabalho, bem como apontar eventuais falhas textuais implícitas.

O texto da peça do Ministério Público contém expressões que expressam contradição, como "[...] determinados momentos, manifesta vontade em realizar o procedimento de esterilização (linhas 11-12)" e do outro lado " [...] noutros, demonstra desinteresse ao não aderir aos tratamentos" (linha 13). Mesmo assim, apesar da contradição, o Ministério Público determina a laqueadura compulsória da requerida mesmo contra a sua vontade (linhas 22- 23), pois se trata de um direito subjetivo (linha 30) da Janaína.

O direito subjetivo é a faculdade ou possibilidade que tem uma pessoa de fazer prevalecer em juízo a sua vontade protegida 
pelo Direito, consubstanciada num interesse (CRETELLA JUINIOR, 1995; REALE, 2012). Ocorre que, a própria definição de direito subjetivo pressupõe vontade.

Como resultado, constatamos uma falha grave de um texto que se pretende argumentativo. Esse tipo de discurso falho é comumente encontrado em textos de teor político, religioso e jurídico. Vê-se, portanto, uma figura textual que o autor Orwell (2005) denominou de "duplipensamento" (neologismo) em seu romance chamado de "Mil Novecentos e Oitenta e Quatro". A figura em questão é um ato de aceitar simultaneamente duas crenças mutualmente contraditórias como corretas (ORWELL, 2005). Segundo o autor, o duplipensamento é

[...] saber e não saber, ter consciência de completa veracidade ao exprimir mentiras cuidadosamente arquitetadas, defender simultaneamente duas opiniões opostas, sabendo-as contraditórias e ainda assim acreditando em ambas; usar a lógica contra a lógica, repudiar a moralidade em nome da moralidade, crer na impossibilidade da democracia e que o Partido era o guardião da democracia; esquecer tudo quanto fosse necessário esquecer, trazê-lo à memória prontamente no momento preciso, e depois torná-lo a esquecer; e, acima de tudo, aplicar esse mesmo processo ao próprio processo. Esta era a sutileza derradeira: induzir conscientemente a inconsciência e então tornar-se inconsciente do ato de hipnose que se acabava de realizar. Até para compreender a palavra "duplipensar" era necessário usar o duplipensar (ORWEL, 2005, p. 36).

O exemplo prático de duplipensar seria tomar como verdadeiro que todos os metais sem exceção são atraídos por um imã e que o metal chumbo não poderia ser atraído por um imã. No caso concreto, o direito subjetivo da requerida e a laqueadura compulsória contra a mesma são ideias incompatíveis entre si que foram tomadas como verdadeiras.

O Ministério Público confessa implicitamente que não sabia da real intenção vontade da requerida (linhas 9, 10, 11, 12, 13 e 14), e mesmo assim em sua peça propõe a esterilização obrigatória com base no direito subjetivo (linha 30) da moradora, direito este que nem sequer existe por estar ausente o elemento fundamental "vontade" da Janaína.

Portanto, qual é vontade real de uma pessoa que perambula sem lucidez e ora aceita a proposta de laqueadura, mas também ora rejeita? Percebe-se que não existe uma vontade livre, consciente e expressa da requerida. Em seguida, o Ministério Público conclui, ignorando totalmente a vontade da moradora, pela laqueadura tubária (linhas 15 - 16). Verifica-se, de plano, outro problema social implícito, que trata da desconsideração da autonomia reprodutiva individual.

Os direitos fundamentais ligados aos direitos reprodutivos foram concretamente lesados nas peças jurídicas. O direito fundamental ao planejamento familiar (art. $226 \$ 7^{\circ}$ da CF), que é extraído da dignidade da mulher (art. $1^{\circ}, \mathrm{III}$, da CF), foi afetado. $\mathrm{O}$ aspecto intrínseco da dignidade da pessoa humana, em que a real vontade de Janaína deveria ser tratada como aspecto central, acabou sendo afastado. A esterilização forçada pretendida pelo MP e atendida pelo Poder Judiciário extirpou a liberdade constitucional de locomoção e a autodeterminação do próprio corpo.

Janaína teve sua autonomia desdenhada. 
Como resultado, não foi tratada como um fim em si mesma ao longo do trâmite do processo em primeira instância. Porém, ela serviu como um fim operativo à ideologia hegemônica do patriarcado. Essa ideologia patriarcal, que coloca as mulheres como "o outro", impede a mulher de "ser para si", de cumprir o papel como sujeita (BEAUVOIR, 1980). O homem branco, mais velho, burguês, rico e preferencialmente heterossexual é visto como o padrão ideal de poder dentro de uma estrutura hierarquizada (SAFFIOTI, 2004). O mundo, dessa forma, passa a funcionar sob a prescrição desse tipo de masculinidade (BEAUVOIR, 1980).

Outro duplipensamento que é praticado por parte tanto do Ministério Público, quanto por parte da autoridade judicial, é que a esterilização forçada não enseja a consagração do direito à saúde ( linha 25, 26, 60 - 67), mas representa uma real violação à integridade. Trata-se de uma violência física. $O$ terceiro desembargador (fls. 191 dos autos) votante do Tribunal de Justiça de São Paulo nos autos do processo destaca:

[...] o que se pedia não era a recuperação da saúde de alguém; mas sim a imposição a terceiro da mutilação de uma capacidade corporal sua, e, subsidiariamente, a condenação de ente estatal resistente ao pleito a pagar multa caso não se desincumbisse de encontrar a paciente e coagi-la à cirurgia.

Tanto o discurso do Ministério Público, quanto o discurso do magistrado, ambos possuíam um pedido potencialmente danoso em face do Município, para que este procedesse a mutilação do órgão reprodutor da Janaína. O problema social em apreço encontrado, portanto, foi a violência de gênero.

Os dois homens, altos funcionários do Esta- do, resolveram proceder a mutilação de outro ser humano com base em quê? Pelo fato de ser dependente química, hipossuficiente e não ter condições financeiras. O Estado reforça as exclusões do patriarcado, estabelecendo, in casu, uma suposta relação paternalista (BOURDIEU, 1999), em que o Poder Judiciário usurpa a decisão da mulher de decidir a respeito do seu planejamento familiar.

O patriarcado acaba reforçando a tendência esterilizante e perpassa os meios de comunicação de massa e os profissionais que atuam na área da saúde, serviço social e em todas as áreas (BARROSO, 1984). Esse tipo de violência contra o aparelho reprodutivo da mulher passa a ser naturalizado, fazendo parte, inclusive, do habitus. A naturalização desse tipo de violência não é de hoje. Em 1981, houve divulgação de uma cartilha do Governo de São Paulo, em que a esterilização é acompanhada da promessa de um bônus especial de "[...] uma vida sexual sem preocupação".

Rememorando Saffioti (2004), o patriarcado se insurge com violência contra aqueles que se apresentam como desvio ou antítese, sobretudo em se tratando de mulher extremamente pobre, negra, que enfrenta problemas relacionados ao alcoolismo e com muitos filhos potencialmente vistos como iguais a ela. Essa operação ideológica dominante (o patriarcado) tenta a todo custo, por meio de diversas práticas sociais, fazer prevalecer o contrato de dominação-exploração dos homens sobre os corpos das mulheres, seguindo as concepções de Pateman (1993).

O pedido do Ministério Público e a decisão liminar reproduzem esse habitus patriarcal. Ambas as peças, obviamente, estão conec- 
tadas, o que remete a próxima fase da análise discursiva, que trata da intertextualidade.

\subsection{Intertextualidade}

A intertextualidade, como já antes tratado, é quando o texto analisado se relaciona com outras fontes.

Tanto os trechos do Ministério Público, quanto os trechos da liminar concedida pelo juiz, ambos estão interligados e se referenciam leis (intertextualidade atribuída). A decisão da primeira instância chega a citar a autora Diniz (linhas 69 - 70).

Na linha 15, constata-se a expressão "[...] não há dúvidas de que somente" e na linhas 21 e 22 temos outra expressão "[...] não resta alternativa ao Ministério Público senão o ajuizamento da presente ação". Ambas estão funcionando como se fossem uma afirmação categórica de verdade (intertextualidade não modalizada) de que a requerida deve ser esterilizada por levar uma vida de drogadição e por ter os filhos sob os cuidados em Casa de Acolhimento, conforme as linhas 2, 3, 4, 5, 10 e 11.

Há também outra funcionalidade dessas expressões, pois estão supondo ocultamente a vontade da requerida em querer receber a cirurgia de laqueadura, já que ela é uma dependente química e tem cinco filhos (intertextualidade destacada).

A normalização pretendida pelo Ministério Público e pelo Judiciário está acobertada por um aparente tecido de legitimidade fundado na lei e na Constituição. Essa capa legal ocultou o preconceito de classe e de vício.

Na análise do discurso em questão, se alguém fala (juiz e promotor), há alguém que não fala (a requerida), pois inexiste indício de audiência da Janaina perante as autoridades nos trechos destacados.

Conforme os fragmentos transcritos da instância de segundo grau que reverteu a decisão, a Janaína não demonstrou pleno e autônomo procedimento para a realização do ato cirúrgico invasivo.

De acordo com relatório informativo do CREAS Centro de Referência Especializado de Assistência Social do Município de Mococa, ao final do ano de 2016 ela teria recebido orientações quanto ao procedimento, sendo agendados exames médicos para tanto; em 23/01/2017, compareceu ela ao CAPS-AD, retirando todos os pedidos de exames já agendados, tendo sido orientada a ir ao PPA procurar a enfermeira responsável pela "rede cegonha", para orientá-la e procurar a referência adequada dentro do serviço; após esta data, não mais procurou o serviço de saúde para essa finalidade, não sendo observada a sua adesão ao procedimento cirúrgico ( fls. 09/10 dos autos).

\section{(..)}

Já no curso deste feito, quando já havia sido deferida a antecipação da tutela de urgência a fls. 30/31, ela foi procurada pela enfermeira responsável da "rede cegonha" da Municipalidade de Mococa, tendo sido encontrada desnutrida, com aparência descuidada e de falta de higiene, relatandouso de álcool diário; e, agendada consulta ginecológica no dia 31/07/2017, deixou de comparecer (fl. 46 dos autos).

Outro fator que agrava a situação, é que nem Ministério Público e nem o magistrado de primeira instância citaram e muito menos examinaram os dispositivos que vão em 
direção contrária à laqueadura compulsória. Esses dispositivos, da própria lei 9.263/1996, foram grifados pelo tribunal de segundo grau:

Art. $1^{\circ} \mathrm{O}$ planejamento familiar é direito de todo cidadão, observado o disposto nesta Lei.

Art. $2^{\circ}$ Para fins desta Lei, entende-se planejamento familiar como o conjunto de ações de regulação da fecundidade que garanta direitos iguais de constituição, limitação ou aumento da prole pela muIher, pelo homem ou pelo casal.

Parágrafo único - É proibida a utilização das ações a que se refere o caput para qualquer tipo de controle demográfico.

\section{$[\ldots]$}

Art. $5^{\circ}$ - É dever do Estado, através do Sistema único de Saúde, em associação, no que couber, às instâncias componentes do sistema educacional, promover condições e recursos informativos, educacionais, técnicos e científicos que assegurem o livre exercício do planejamento familiar.

\section{$[\ldots]$}

Art. 10. Somente é permitida a esterilização voluntária nas seguintes situações:

I - em homens e mulheres com capacidade civil plena e maiores de vinte e cinco anos de idade ou, pelo menos, com dois filhos vivos, desde que observado o prazo mínimo de sessenta dias entre a manifestação da vontade e o ato cirúrgico, período no qual será propiciado à pessoa interessada acesso a serviço de regulação da fecundidade, incluindo aconselhamento por equipe multidisciplinar, visan- do desencorajar a esterilização precoce;

$[\ldots]$

$\S 3^{\circ}$ Não será considerada a manifestação de vontade, na forma do $\S 1^{\circ}$, expressa durante ocorrência de alterações na capacidade de discernimento por influência de álcool, drogas, estados emocionais alterados ou incapacidade mental temporária ou permanente.

$[\ldots]$

$\S 6^{\circ}$ A esterilização cirúrgica em pessoas absolutamente incapazes somente poderá ocorrer mediante autorização judicial, regulamentada na forma da Lei.

Diante disso, indaga-se: se a cidadã fosse rica teria alguma mutilação compulsória expedida por algum órgão do Estado? E se fosse um homem rico e branco? Seria esterilizado?

Janaína, por ser a antítese do patriarcado rico e branco, por ocupar demasiadamente os espaços ante o grande número de filhos de mesma condição e origem que ela, tem de ser internada e esterilizada para que não se reproduza e ocupe mais os espaços. Este foi o código social implícito abstraído, localizado provavelmente no inconsciente coletivo, conforme a análise crítica interpretativa e intertextual. Seria uma forma de repulsa da classe dominante em ver pobres ocupando demais os espaços nos termos da leitura de Mendonça e Jordão (2014), inclusive no campo reprodutivo. Como o próprio segundo desembargador votante do tribunal salientou,

[...] a esterilização pedida nos autos não é a de natalidade, pois não tem caráter geral e impessoal, mas considera as qualidades subjetivas da paciente de aspectos 
financeiros, social, educacional, e eventuais vícios, equiparando-se à castração dos anormais e criminosos, situação que não tem a permissão constitucional brasileira.

Em suma, trata-se de inadmissível preconceito social contra os menos favorecidos, uma vez que existem alternativas jurídicas disponíveis de assistência social e de orientação de planejamento familiar (fls. 177 dos autos).

Ao ser um padrão desviante, o Ministério Público e o Poder Judiciário da primeira instância buscaram legitimar a violência responsabilizando a vítima pela omissão do próprio Estado quanto ao dever de tornar eficiente a implementação de políticas públicas que garantam moradia, alimentação, acesso ao emprego e renda. Não houve no discurso reflexões e nem garantias que visem a autonomia reprodutiva feminina e inclusão dos mais pobres. Buscou-se, antes de tudo, uma responsabilidade individual da Janaína por viver na extrema pobreza e por se encontrar abandonada à própria sorte. Sendo assim, em vez de o Estado e de a sociedade realizarem um exercício de autorresponsabilização, dando plenas condições à vítima de decidir sobre o seu planejamento familiar, resolveram mutilá-la motivados pelo habitus de uma sociedade regida pela dominação masculina violenta.

Esse regime de dominação masculina acaba incidindo na intensa discriminação contra a mulher e no controle da sua sexualidade e da capacidade reprodutiva (SAFFIOTI, 2004). Assim, o controle do número de fiIhos acaba, muitas vezes, ficando nas mãos masculinas por meio de agentes do Estado.

O patriarcado, conforme Saffioti (2004), está espalhado em todos os cantos, ainda mais na esfera estatal. Essa especificidade pode representar um real problema para o direito. Percebeu-se, no caso concreto, que o patriarcado operou através da aplicação de normas performáticas, abertas por meio de subsunção direta. Os textos de lei foram aplicados de modo "recortado", seletivo, sem maior detalhamento e desprezando outras normas ou partes das mesmas normas que vociferavam em sentido contrário.

Dessa maneira, a dignidade da mulher e o direito sobre o próprio corpo assegurados pela Constituição foram abandonados. Em vez de a Lei Maior de 1988 ser aplicada, acabou sendo aplicada a prescrição patriarcal. O patriarcado reside no subconsciente e no habitus de muitos membros da sociedade, que vão desde as classes mais desfavorecidas até as classes mais abastadas, penetrando até no jeito de ser das elites estatais. No entanto, são necessárias algumas iniciativas para mudar esse quadro.

\subsection{Mudança social}

Os trabalhos acadêmicos de cunho sociológico e jurídico como este visam justamente questionar essa ordem patriarcal hierarquizada por meio da análise discursiva crítica.

Como iniciativa de mudança, o escopo aqui visa ajudar a impulsionar os movimentos acadêmicos críticos e democráticos que visem implementar o princípio da máxima efetividade do direito à igualdade entre homens e mulheres (art. $5^{\circ}$, I da CF), sobretudo no campo da autonomia reprodutiva feminina.

Quanto maiores forem a impulsão e a importância de trabalhos críticos sobre o referido tema, por dedução lógica, maior será a chance de o debate transcender as fronteiras da academia e atingir as massas popu- 
lares. A consciência crítica sobre o valor da autonomia humana e sobre a igualdade entre homens e mulheres pode enfraquecer a hegemonia do patriarcado, o que tem como consequência a menor visibilidade dos discursos opressores.

A esterilização compulsória não foi o primeiro, e provavelmente, não será o último caso no Brasil. $\bigcirc$ fortalecimento dos direitos fundamentais, da liberdade de escolha da muIher e da igualdade entre os sexos podem, porém, resultar na mudança de habitus. Em razão disso, a violência ocorrida no caso concreto passaria a ser cada vez mais rara e ela poderia ser, em vez de tema polêmico, uma prática desnaturalizada, imoral e incontestavelmente inconstitucional.

Outra linha de proposta em reação às posturas que rebaixam as mulheres para variadas exclusões, sobretudo no campo da autonomia reprodutiva, seria o progressivo "empoderamento" dos movimentos de muIheres. Empoderar leva em seu bojo a ideia de poder lutar, resistir e se opor à hegemonia patriarcal, hegemonia esta que subordina a mulher em vários contextos, como o social, político, econômico e, até mesmo jurídico, como ocorreu no caso concreto (LISBOA, 2008).

O empoderamento visa reconhecer, valorizar as mulheres, afirmar as suas condições de igualdade material perante os homens, questionar, desafiar as relações patriarcais e sobretudo o privilégio de gênero (LISBOA, 2008). O empoderamento pretende uma modificação radical das estruturas e dos processos que colocam a mulher na condição "do outro", de subalterna. Desse modo, empoderar a mulher implica o direito de ela pleitear a autonomia e o controle sobre o próprio corpo, a sua liberdade sexual e re- produtiva, de ir e vir, de exercer todos esses direitos constitucionais e humanos sem qualquer tipo de discriminação, coerção ou abuso por parte do Estado ou de particulares (LISBOA, 2008). Para tal, o despertar da consciência por meio dos movimentos das mulheres e de trabalhos acadêmicos com o uso da ciência crítica é de fundamental importância para anular ou diminuir a desigualdade factual de gênero, que é ainda muito evidente nessa sociedade governada pelos ditames patriarcais.

\section{CONCLUSÃO}

O presente artigo se valeu da análise linguística com o foco na análise da realidade social cujo propósito foi de descrever, analisar e propor soluções em face de um problema social apresentado em dada situação concreta.

O problema social no estudo de caso orbitou em torno da violência judicial de gênero contra a mulher, fruto da operação do patriarcado. Essa violência foi escondida atrás de uma semântica travestida de erudita. Assim sendo, houve a mutilação da autonomia feminina e por consequência o princípio constitucional de maior estatura na Constituição Federal: a dignidade da pessoa humana. O direito de decidir sobre os destinos da própria vida, de se autogovernar, de elaborar suas próprias leis internas para depois segui-las, em suma, a livre vontade da vítima foi usurpada pela vontade eugenista do Poder Judiciário de primeira instância e do Ministério Público. Isso foi aclarado por via análise do discurso crítica, método de procedimento que permite empiricamente revelar os propósitos, crenças, valores, visão de mundo e manipulação ideológica dos autores das práticas sociais.

O processo, conforme o que foi abstraído da 
análise, fundamentou-se em normas "cortadas pela metade", pois a Lei n. 9.263/96 proíbe expressamente a esterilização de pessoa capaz sem o seu consentimento. As remissões aos dispositivos de leis e jurisprudências passadas funcionaram sob a chave da intertextualidade manifesta, destacada e intertextualidade não modalizada.

As peças do texto apresentaram inconsistências e quebras de lógica, o que caracterizou o duplipensamento, segundo a concepção de Orwell (2005). Em outras palavras, afirmações contraditórias do MP chanceladas pelo judiciário foram tidas como válidas ao longo dos trechos retirados dos autos.

Constata-se que a esterilização de mulheres sem o consentimento não é o primeiro caso no Brasil e muito menos no mundo. O domínio sobre o campo decisório das mulheres é decorrente do regime patriarcal. Para mudar esse cenário, porém, é de fundamental importância o empoderamento feminino por meio da luta dos movimentos organizados de mulheres para se lograr o sonhado direito à igualdade. No mesmo sentido, faz-se importante o desenvolvimento da ciência crítica no campo do Direito.

Este trabalho se torna uma pequena contribuição para a área da ciência crítica no campo jurídico e visa continuar movimentando e fomentando o debate científico em torno dos direitos das mulheres. Espera-se que o resultado desta Pesquisa Empírica do Direito (PED), utilizada por meio da pesquisa documental e bibliográfica, tenha contribuído para a compreensão de como o relacionamento entre o discurso e a realidade social é de suma importância para compreender - Direito sendo usado na prática, seja para alcançar a justiça social, seja como uma roldana do patriarcado.

\section{REFERÊNCIAS}

Alves, J. (2010, junho 5). O Planejamento familiar no Brasil. UFRJ. Recuperado de http://www.ie.ufrj.br/ aparte/pdfs/texto_pf_jeda_05jun10.pdf.

Arilha, M., \& Berquó E. (2009). Cairo + 15: trajetórias globais e caminhos brasileiros em saúde reprodutiva e direitos reprodutivos. In: Associação Brasileira de Estudos de População e Fundo de População das Nações Unidas. Brasil, 75 anos após a Conferência do Cairo (p. 67- 119). Campinas: ABEP/UNFPA.

Assis, F., \& Bertolini, F. (2018, junho 21). TJ-SP concede liberdade para mulher que fez laqueadura determinada pela Justiça. Recuperado de https://gl.globo.com/ sp/sao-carlos-regiao/noticia/liminar-do-tj-sp-concede-liberdade-para-mulher-esterilizada-apos-decisao-da-justica.ghtml.

Barboza, H. (2008). Reprodução humana como direito fundamental. In: Direito, C., Cançado Trindade, A., \& Pereira, A. (Orgs.). Novas perspectivas do direito internacional contemporâneo (pp.777-801). Rio de Janeiro: Renovar.

Barboza, H., \& Almeida Junior, V. (2017). (Des) Igualdade de gênero: restrições à autonomia da mulher. Pensar-Revista de Ciências Jurídicas, v. 22, n. 1, p. 240-271. Barretto, V. (2010). O fetiche dos direitos humanos e outros temas. Rio de Janeiro: Lumen Juris.

Barroso, C. (1984). Esterilização feminina: liberdade e opressão. Revista de Saúde Pública, v. 18, p. 170-180.

Barroso, L. (2012). A dignidade da pessoa humana no direito constitucional contemporâneo: a construção de um conceito jurídico à luz da jurisprudência mundial. Belo Horizonte: Fórum.

Batista Junior, J., Sato, D., \& Melo, I. (Orgs.) (2018). Análise de discurso crítica para linguistas e não linguistas. São Paulo: Parábola.

Beauvoir, S. (1980). O segundo sexo (S. Milliet, Trad). Rio de Janeiro: Nova Fronteira.

Bourdieu, P. (1999). A dominação masculina (M. Kühner, Trad). Rio de Janeiro: Bertrand Brasil.

Buglione, S. (2003). Reprodução, esterilização e justiça: os pressupostos liberais e utilitaristas na construção do sujeito de direito. Dissertação (Mestrado em Direito) - Faculdade de Direito da Pontifícia Universidade Católica do Rio Grande do Sul, Porto Alegre, RS, Brasil.

Câmara dos Deputados. Relatório n. 2, de 1993 - relatório final da Comissão Parlamentar Mista de Inquérito 
destinada a examinar a incidência de esterilização em massa de mulheres no Brasil. Recuperado de https://legis.senado.leg.br/sdleg-getter/documento?d$m=4350842 \& t s=1547952408321$ \&disposition=inline.

Chouliaraki, L., \& Fairclough, N. (1999). Discourse in late modernity: rethinking critical discourse analysis. Edimburgo: Edinburgh University Press.

Colares, V. (2014). Análise Crítica do Discurso Jurídico (ACDJ): o caso Genelva ea (im) procedência da mudança de nome. ReVEL, v. 12, n. 23, 120-147.

Conde de Mirândola e Concórdia, G. (1999). A dignidade do homem (L. Feracine, Trad). Campo Grande: Solivros.

Constituição da República Federativa do Brasil de 1988. Recuperado de http://www2.camara.leg.br/atividadelegislativa/legislacao/Constituicoes_Brasileiras/ constituicao1988.html..

Correa, S., \& Petchesky, R. (1996). Direitos sexuais e reprodutivos: uma perspectiva feminista. Physis: Revista de Saúde Coletiva, v. 6, 147-177.

Crenshaw, K. (2002). Documento para o encontro de especialistas em aspectos da discriminação racial relativos ao gênero. Revista Estudos Feministas, v. 10, n. 1, p. 171.

Cretella Júnior, J. (1995). Dos atos administrativos especiais (2a. ed.). Rio de Janeiro: Forense.

Fairclough, N. (2001). Discurso e mudança social ( I. Maya, Trad). Brasília: Universidade de Brasília.

Fairclough, N. (2003). analysing discourse: textual analysis for social research. london: Psychology Press. Ferreira, M. (2014). A mulher como o «outro»: a filosofia e a identidade feminina. Filosofia. Revista da Faculdade de Letras da Universidade do Porto, v. 24, n. 1, $139-153$.

G1 Globo (2018, junho 24). Justiça determina esterilização de mulher e causa polêmica. Recuperado de http://g1.globo.com/fantastico/noticia/2018/06/justica-determina-esterilizacao-de-mulher-e-causa-polemica.html

Gomes, N., Diniz, N., Araújo, A., \& Coelho, T. (2007). Compreendendo a violência doméstica a partir das categorias gênero e geração. Acta Paul Enferm, v. 20, n. 4, 504-508. Recuperado de http:// wWW.scielo.br/scielo.php?script=sci_arttext\&pi$\mathrm{d}=$ S0103-21002007000400020

Governo de São Paulo. (1981). Fundo de Assistência Social do Palácio do Governo. CARTILHA pró-família, São Paulo.

Iurconvite, A. (2007). Os direitos fundamentais: suas dimensões e sua incidência na Constituição. Âmbito Jurídico, v. 10, n. 48, 2007. Recuperado de https://ambitojuridico.com.br/cadernos/direito-constitucional/ os-direitos-fundamentais-suas-dimensoes-e-sua-incidencia-na-constituicao/

Jardim, R. (2005). Esterilização feminina na ótica dos direitos reprodutivos, da ética e do controle de natalidade. Revista Jus Navigandi, ISSN 1518-4862, Teresina, v. 10, n. 793, set. 2005. Recuperado de em: <https:// jus.com.br/artigos/7212

Lei n. 3.071, de $1^{\circ}$ de Janeiro de 1916. Recuperado de http://www2.camara.leg.br/legin/fed/lei/1910-1919/lei-3071-1-janeiro-1916-397989-publicacaooriginal-1-pl. html

Lei n. 9.263, de 12 de janeiro de 1996. Regula o § $7^{\circ}$ do art. 226 da Constituição Federal, que trata do planejamento familiar, estabelece penalidades e dá outras providências. Recuperado de http://www.planalto. gov.br/ccivil_03/LEIS/L9263.htm.

Lisboa, T. (2008). O empoderamento como estratégia de inclusão das mulheres nas políticas sociais. Fazendo gênero, v. 8, 1-6. Recuperado de http://www.fazendogenero.ufsc.br/8/sts/ST11/ Teresa_Kleba_Lisboa_11.pdf

Louro, G. (1997). Gênero, sexualidade e educação. Uma perspectiva pós estruturalista. Petrópolis: Vozes.

Martins-Costa, J. (2001). As interfaces entre a bioética e o direito. In: Clotet, J. (Org.). Bioética. Porto Alegre: EDIPUCRS.

Mello, J. (2016, outubro 10). Membros do MP e do Judiciário estão entre os mais bem pagos do país. Recuperado de https://jornalggn. com.br/gestao-publica/membros-do-mp-e-do-judiciario-estao-entre-os-mais-bem-pagos-do-pais/

Melo, C. (2009). Curso de Direito Administrativo. São Paulo: Malheiros.

Melo, I. (2018). Histórico da análise do discurso crítica. In: Batista Junior, J., Sato, D., \& Melo, I. (Orgs.). Análise de discurso crítica para linguistas e não linguistas (pp. 21 -35). São Paulo: Parábola,

Mendonça, M., \& Jordão, J. (2014). Nojo de pobre: representações do popular e preconceito de classe. Contemporânea, v. 12, n. 1. Recuperado de file:///C:/Users/ User/Downloads/10094-42307-1-PB\%20(2).pdf Moraes, M. (2010). Na medida da pessoa humana. Rio de Janeiro: Renovar.

Orwell, G. (2005). 1984 (W. Velloso, Trad.). São Paulo: Nacional.

Organização das Nações Unidas (2018, junho 20). ONU manifesta preocupação com esterilização de mulher em situação de rua em SP. Recuperado de https://nacoesunidas.org/onu-manifesta-preocupacao-com-es- 
terilizacao-de-mulher-situacao-rua-sp/

Organização das Nações Unidas (n.d.). Progresso das Mulheres no Mundo: transformar as economias para realizar os direitos, lançado em 27 de abril de 2015. Recuperado de http://progress.unwomen.org/ en/2015/\#collapseThree

Pateman, C. (1993). O contrato sexual (M. Avancini, Trad.). São Paulo: Paz e Terra.

Pérez, J. (1986). La Dignidad de la persona. Madrid: Civitas.

Pinheiro, L., Fontoura, N., Querino, A., Bonetti, A., \& Rosa, W. (2015). Retrato das desigualdades de gênero e raça. Brasília: Ipea; SPM: UNIFEM.

Rabenhorst, E. (2010). O valor da pessoa humana e o valor da natureza. In: Almeida Filho, A., \& Melgaré, P. (Orgs.). Dignidade da pessoa humana-fundamentos e critérios Interpretativos. São Paulo: Malheiros.

Reale, M. (2012). Lições preliminares de direito. São Paulo: Saraiva.

Redação Revista Forum (n.d.). ADVOGADO posta mensagem sobre mulher esterilizada sem consentimento: "O caso é grotesco. " Recuperado de https:// www.revistaforum.com.br/advogado-posta-mensagem-sobre-mulher-esterilizada-sem-consentimento-o-caso-e-grotesco/>.

Ribeiro, D. (2018). O que é lugar de fala? Belo Horizonte: Letramento.

Rodotà, S. (2007). Dal soggetto alla persona. Napoli: Editoriale Scientifica.

Rodotà, S. (2006). La vita e le regole: tra diritto e non diritto. Milano: Feltrinelli Editore.

Saffioti, H. (2001). Contribuições feministas para o estudo da violência de gênero. Cadernos pagu, n. 16, 115136.

Saffioti, H. (2004). Gênero, patriarcado, violência. São Paulo: Perseu Abramo.

Santos, S. (2012). As teorias feministas e a evolução das relações de gênero na sociedade. Publicatio UEPG: Ciências Sociais Aplicadas, v. 20, n. 2, 213-223.

Sarlet, I. (2009). Dignidade da Pessoa Humana e Direito Fundamental na Constituição Federal de 1988. Porto Alegre: Livraria do Advogado.

Sarmento, D. (2016). Dignidade da pessoa humana: conteúdo, trajetórias e metodologia. Belo Horizonte: Editora Fórum.

Sarmento, D. (2005). Legalização do aborto e Constituição. Revista de Direito Administrativo, v. 240, 43-82. Sousa, E. (2010). Sexualidade(s) e direitos humanos: "casos difíceis" e respostas (corretas?) do judiciário.
Encontro Nacional do Conpedi. Anais... Fortaleza: 2010, 4905-4917.

Tepedino, G. (1999). A tutela da personalidade no ordenamento civil-constitucional brasileiro. Temas de Direito Civil, v. 3, p. 23-58.

Thompson, J. B. (1995). Ideologia e cultura moderna: teoria social crítica na era dos meios de comunicação de massa. Petrópolis: Vozes.

TribunaldeJustiça deSãoPaulo(2017).Sentençajudicial. Processo número:1001521-57.2017.8.26.0360. Recuperado de :https://esaj.tjsp.jus.br/cposg/search.do?conversationld=\&paginaConsulta=1\&localPesquisa.cdLocal=-1\&cbPesquisa=NMPARTE\&tipoNuProcesso=UNIFICADO\&dePesquisa=Jana\%C3\%ADna+Aparecida+Quirino\&uuidCaptcha=\&pbEnviar=Pesquisar\#?cdDocumento $=49$

TV Direta Mococa (2018). PROGRAMA SAÚDE COM O $2^{\circ}$ PROMOTOR DE JUSTIÇA DR. FREDERICO BARRUFFINI. [Arquivo de vídeo]. Recuperado de https://www. youtube.com/watch?v=78vnwpHFXaM\&t=566s>

TV Direta Mococa (2018).CIDA CILLI ENTREVISTA O JUIZ DR DJALMA, QUE FALA SOBRE FEMINICÍDIO. [Arquivo de vídeo]. Recuperado de https://www.youtube.com/watch?v=ShXyN49AS5E

Watanabe, L. A. (2001). O amigo do sábio. In: Jornal de resenhas: seis anos (de abril de 1995 a abril de 2001). São Paulo: Discurso Editorial.

Wodak, R. (2001). What CDA is about-a summary of its history, important concepts and its developments. Methods of critical discourse analysis, v. 1, 1-13.

Data de submissão: 22/07/2019

Data de aceite: 15/11/2019 